\title{
Earth to Air Heat Exchanger and Its Applications in Arid Regions - An Updated Review
}

\author{
Nasreddine Sakhri ${ }^{1}$, Younes Menni ${ }^{2}$, Ali J. Chamkha ${ }^{3 *}$, Mohamed Salmi ${ }^{4}$, Houari Ameur ${ }^{5}$ \\ ${ }^{1}$ Laboratory of Energy in Arid Areas (ENERGARID), University of Bechar, B.P. 417, 08000, Bechar, Algeria \\ ${ }^{2}$ Unit of Research on Materials and Renewable Energies, Department of Physics, Faculty of Sciences, Abou Bekr Belkaid \\ University, B.P. 119, 13000, Tlemcen, Algeria \\ ${ }^{3}$ Mechanical Engineering Department, Prince Sultan Endowment for Energy and Environment, Prince Mohammad Bin Fahd \\ University, Al-Khobar 31952, Saudi Arabia \\ ${ }^{4}$ Department of Physics, University of M'sila, B.P. 1713, M'sila, 28000, Algeria \\ ${ }^{5}$ Department of Technology, University Center Salhi Ahmed of Naâma (Ctr Univ Naâma), B.P. 66, 45000, Naâma, Algeria
}

Corresponding Author Email: achamkha@pmu.edu.sa

https://doi.org/10.18280/ti-ijes.640113

Received: 12 October 2019

Accepted: 16 January 2020

\section{Keywords:}

earth to air heat exchanger, air ground heat exchanger, geothermal source, arid and desert regions, semi-arid and arid regions

\begin{abstract}
Earth to Air Heat Exchanger ETAHE or Air Ground Heat Exchanger (AGHE) is a renewable technique based on geothermal source used for many centuries in arid and desert regions and considered as a principal element of vernacular and traditional architecture. Arid regions are characterized by a severe winter and summer weather conditions leads to a large thermal discomfort for the big part of the year. Many researchers studied the potentials of this technique to ensure thermal comfort inside buildings for summer and winter seasons. The present study is a review of numerical, experimental, parametric and economic studies of an earth to air heat exchanger with a focus on its application in semi-arid and arid regions. Using an air-to-ground heat exchanger for thermal comfort requires a deep understanding of geothermal deposits and these natural potentials and particularly in desert and arid regions.
\end{abstract}

\section{INTRODUCTION}

Thermal comfort research returns to the onset of humanity on earth. Man has always sought to condition his living areas to ensure stability. Recent building architectural design highlighted the advantage and potential of natural ventilation systems for occupant's thermal comfort. Natural ventilation has become a solution not only to reduce energy and cost, but also to provide thermal comfort and good indoor air quality [1-5]. An example of such innovative ventilation is the wind tower, solar chimney and earth to air heat exchanger.

Allard [6] defines the optimal air quality as air free of contaminants or harmful materials that can pose a risk to occupant's health, which could cause irritation and discomfort. Natural ventilation provides fresh air for occupants through sustainable and energy-efficient methods [7]. Several numerical studies [8-18] and experimental studies [19-20] were conducted to investigate potentials and influencing parameters on natural ventilation.

\section{AIR-TO-GROUND HEAT EXCHANGER}

Air-ground heat exchanger (or Canadian underground tube) is an ecological, renewable and passive technique (without energy consumption) used since 3000 years B.C by the population of arid regions for conditioning and thermal comfort of their houses [21]. The principle is simple, a pipe of good thermal conductivity (steel, PVC, etc.) is buried at a certain depth where the annual temperature of the subsoil remains unchanged during the year [22]. Air, generally used as working fluid conducted heat transfers during its passage inside the tube where the ground work as heat or sink source due to its heat storage capacity [23]. It result two main thermal regimes:

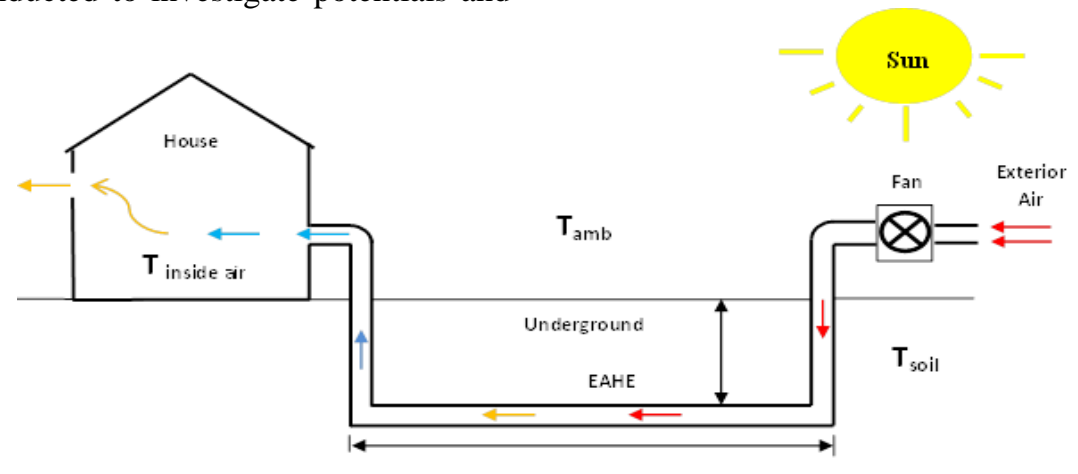

Figure 1. Air-ground heat exchanger in operation during the day and summer period 
During the day and the summer period (see Figure 1), the outdoor air temperature $\mathrm{T}_{\text {ext }}$ is higher than the temperature of the subsoil $\mathrm{T}_{\text {soil }}$. The air is pulsed naturally (by prevailing winds) or mechanically (by fan) inside the buried tube where it exchanges heat with the surrounding layer by conduction and convection where ground works as sink source and air loses some degree during its passage. Air will be injected directly into the building which improves cooling or natural ventilation [24-26].
During night and winter period (see Figure 2), outside air temperature is lower than the air temperature inside the building. Ground in this case work as a heating source to increase the temperature of the air passing through the device or the $\mathrm{T}_{\text {air outlet }}>\mathrm{T}_{\text {air intlet. The result is a preheating of air }}$ injected to the building, more airflow and improvement of occupant's thermal comfort. The ability to work during all seasons of the year (winter and summer) shows the potential of this technique [27].

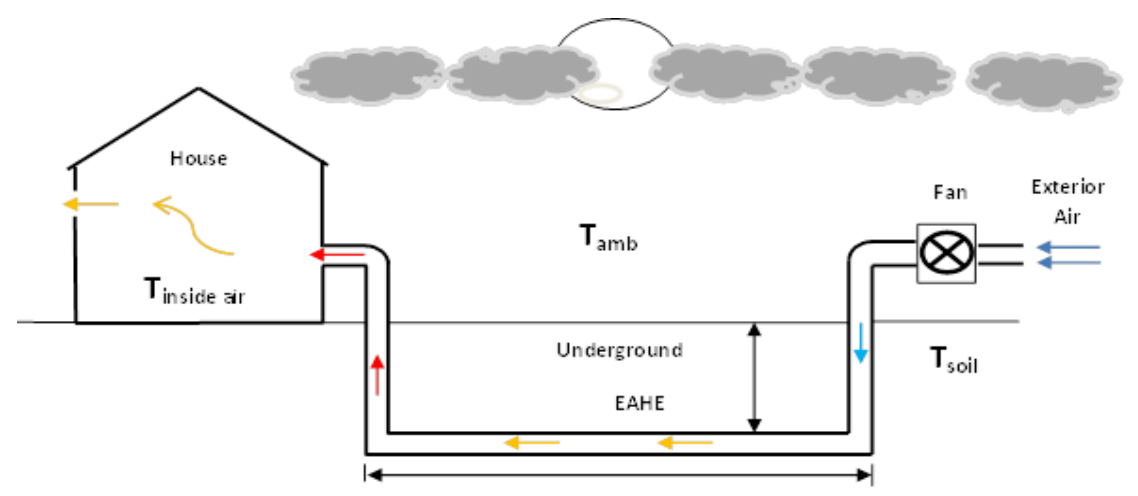

Figure 2. Air-ground heat exchanger operating during the night and winter period

\section{TYPES OF HEAT EXCHANGERS}

Heat exchangers can be classified according to:

\subsection{Air flow circuit}

3.1. Closed loop, see Figure 3(a)

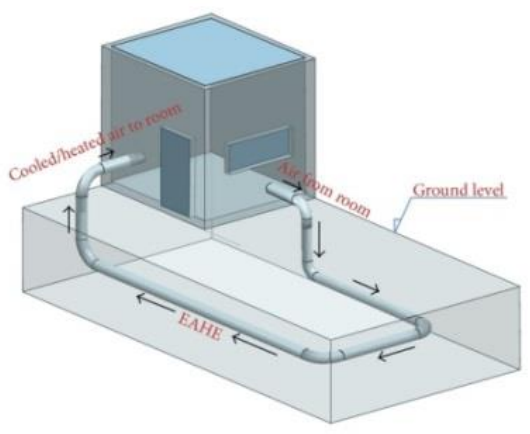

\subsection{Open loop, see Figure 3(b)}

3.3. Hybrid system, where the EAHE is used with air conditioning systems to reduce energy consumption and improve the system performance factor. Renewable techniques can also be combined with EAHE such as wind tower, solar chimney, etc.

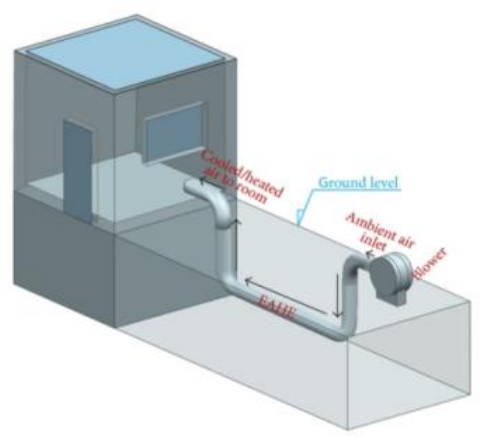

Figure 3. EAHE with (a) closed loop and (b) open loop [28]

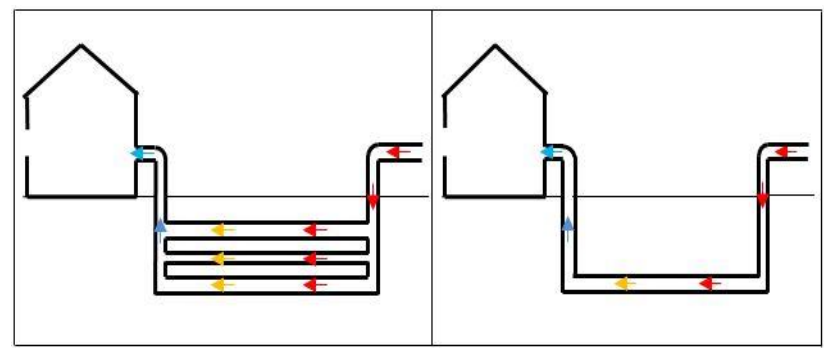

Figure 4. (a) Single tube EAHE and (b) multiple tubes EAHE system

\subsection{Arrangement of buried tubes}

3.2.1. Single tube system, see Figure 4(a)

3.2.2 Several tubes system, see Figure 4(a)

\subsection{Alignment of the buried tubes}

3.3.1 Horizontal EAHE, see Figure 5(a)

3.3.2 Vertical EAHE, see Figure 5(b) 


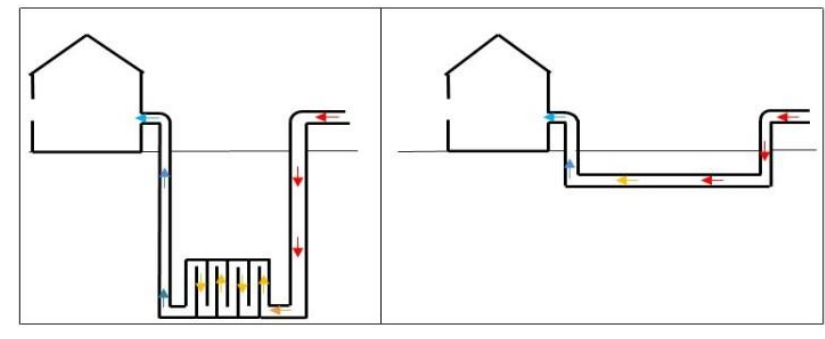

Figure 5. (a) Vertical and (b) horizontal earth to air heat exchanger

\section{FACTORS INFLUENCING THE PERFORMANCE AND OPERATION OF AGHE}

- Geographic location

- Climatic condition;

- Composition and treatment of soil surface covering;

- Physical properties of soil (moisture content, soil density, soil mineral composition, shape of soil particles, etc.);

- Thermal properties of soil (thermal conductivity, thermal diffusivity of the soil, penetration length)

- Floor gluing with pipes;

- Composition of the backfill material;

- Temperature and air velocity;

- Relative humidity of the air;

- Parameters related to the pipe: material (PVC, steel, etc.), pipe length, diameter, thickness;

- Depth of buried pipe;

- Spacing between the pipes;

- Roughness of the pipe;

- Thermal insulation at the outlet of the pipe;

- Running time; and

- Sensitive and latent heat transfer.

\section{EAHE STUDIES REVIEW}

Many researchers around the world have conducted numerical and experimental research to highlight the potentials of this technique. All begin with the geothermal source of the location where the good knowledge of the vertical profile of the temperature of the ground to know at which depth the tube of the exchanger will be buried. Several numerical models are developed and used for vertical subsoil temperature profile prediction. Mihalakakou et al. [29] presented a model for predicting the daily and annual change in soil surface temperature. Popiel et al. [30] conducted insitu soil measurements in Poland between the summer of 1999 and the spring of 2001. Al-Ajmi et al. [31] propose a mathematical model to derive the profile of soil temperature in desert and arid regions.

Bojic et al. [32] have developed a two-dimensional model that estimates heat transfer between buried pipes and the subsoil. The model divides the subsoil into homogeneous and isotropic layers to facilitate the identification of existing thermal regimes. Paepe and Willems [33] simulated the operation of an EAHE under real climatic conditions. Gauthier et al. [34] developed a 3D model to predict the characteristics of circular and square EAHEs. The effect of energy accumulated in the ground on the functioning of the technique is studied by Bojic et al. [35]. The technique of earth to air heat exchangers has aroused the intention of researchers who have tried to model it numerically and study it experimentally. Chaturved and Bartaria [36] studied the cooling capacity of underground pipes. Also, the parameters affecting the operation of the air-ground heat exchanger technique for passive cooling have been studied. Several works [37-41] discuss numerical, parametric, experimental and economic studies carried out on the technique of air-toground heat exchangers.

The first experimental study on air-ground heat exchangers was conducted by Trombe et al. [42]. A tube of $48 \mathrm{~m}$ length and diameter of $0.2 \mathrm{~m}$ buried at $2.5 \mathrm{~m}$ underground was capable to create a difference of $10^{\circ} \mathrm{C}$ between the air temperature entering and leaving the system. Tzaferis et al. [43] conducted a numerical and experimental study of performance an air-to-ground heat exchanger made of PVC pipes buried at a depth of $1.1 \mathrm{~m}$. Coherences between the numerical and experimental results have been found which validates the new model for designing purposes. Vaz et al. [44] studied experimentally and numerically by a calculation code based on the finite volume method (FLUENT) of distribution variation of the annual temperature inside a buried pipe. The obtained results show that the model was able to predict the temperature distribution with $15 \%$ for the biggest difference. Ghosal et al. [45] found an increase of 6$7^{\circ} \mathrm{C}$ in winter and a $3-4^{\circ}$ reduction in summer within an agricultural greenhouse integrated to an EAHE. An experimental study conducted by Tiwari et al. [46] on an EAHE with continuous operation connected to a greenhouse confirms its capacities to function throughout the year and with different climatic conditions.

Bansal et al. [47] conducted an experimental and numerical study using a computational code on the influence of soil type with different conductivity $(0.52,2.0$ and $4.0 \mathrm{~W} /$ $\mathrm{m} . \mathrm{K})$ on the efficiency of air-ground heat exchanger with 100 $\mathrm{m}$ length, $0.2 \mathrm{~m}$ diameter and air velocity of $5 \mathrm{~m} / \mathrm{s}$ in the hot and dry region of Ajmer (India). They found that the air outlet temperature equal to $18.4^{\circ} \mathrm{C}, 18.7^{\circ} \mathrm{C}$ and $18.4^{\circ} \mathrm{C}$ for a thermal conductivity of $0.52,2$ and $4 \mathrm{~W} / \mathrm{m}$. K. The authors used a new parameter to evaluate the technique performance 'Derating Factor'. Haorong et al. [48] studied experimentally the coupling of EAHE and the solar chimney. They found that the new system was able to maintain a comfortable thermal environment inside the building that meets ASHRAE thermal comfort standards. A coupling between air-to-ground heat exchanger technology and a conventional compression air conditioning system has been questioned by Misra et al. [49]. EAHE is used to cool the condenser of the refrigerant circuit. The new hybrid system was able to reduce $18.1 \%$ of energy consumption. Soni et al. [50] have conducted an experimental study of a coupling between an EAHE and a conventional air conditioning system to ensure thermal comfort and achieve energy savings. The new hybrid system was able to reduce significantly energy consumption compared to a conventional air conditioning system.

In Algeria, an experimental study at the University of Biskra on PVC air-to-ground heat exchanger of $53.16 \mathrm{~m}$ length and $110 \mathrm{~mm}$ diameter buried at a depth of $3 \mathrm{~m}$ with 71 hours of continuous working regime was carried out by Belloufi et al. [51]. The temperature reduction reaches $18.06^{\circ} \mathrm{C}$ and the thermal efficiency reaches $78.96 \%$. Menhoudj al. [52] studied the energy performance of an airground heat exchanger for buildings cooling in the region of Ghardaïa (South-east of Algeria). Sahli et al. [53] developed 
a one-dimensional numerical model to predict the performance of an air-ground heat exchanger with different depths dedicated to heating and cooling of buildings situated in South-west of Algeria (Béchar) by varying two parameters: the Reynolds number and the form factor. The simulation results are validated against experimental results. They found a good agreement between the numerical and experimental results. Misra et al. [54] conducted a study on the influence of soil moisture on thermal performance of an air-to-ground heat exchanger. They found that by changing the nature of the soil from dry to wet, the length of EAHE can be reduced from 14 to $12 \mathrm{~m}$.

Kappler et al. [55] studied experimentally the use of a buried water tank as a heat accumulator. The results show that this technique has been able to ensure summer and winter thermal comfort. Jakhar et al. [56] studied numerically with TRNSYS 17 simulation Tools an EAHE and solar heating system. The study is validated with experimental results for the climatic conditions of Ajmer (India) for the winter period. They found that a system with $37 \mathrm{~m}$ EAHE, buried at $3.7 \mathrm{~m}$ depth was able to meet the required heating requirements. Chiesa [57] presents a simplified method for predicting the potentials of this technique taking into account the parameters that influence its functioning (climate, soil). Congedo et al. [58] studied the horizontal air-ground heat exchanger numerically in the summer and winter Mediterranean climatic conditions. The system was able to reduce significantly the use of air conditioning system. Wei al. [59] conducted a numerical study of fan replacement by a thermal draw system within a ventilated casing for the Chongqing Arid Region (China). They found that the new system was able to provide a cooling capacity of $56.3 \mathrm{kWh}$, and a heating capacity of $111.1 \mathrm{kWh}$ for the warmest and coldest day of the ear.

A 1D model based on temperature and relative humidity is developed and tested by $\mathrm{Su}$ et al. [60] to study quantitatively and qualitatively the performance of the air-ground heat exchanger technique. Ramírez-Dávila et al. [61] conducted a numerical study and simulation of EAHE's performance for heating and cooling in 3 cities in Mexico. Each city is characterized by different climatic conditions. JuárezChihuahua characterized by a hot summer and cold winter; Mexico City with a moderate climate and Mérida-Yucatán with a hot summer. They found that EAHE performs better in summer than in winter. The temperature of the air decreases from 3.2 to $6.6^{\circ} \mathrm{C}$ in summer and increases from 2.1 to $2.7^{\circ} \mathrm{C}$ in winter. Shukla et al. [62] modelled thermal behavior of an agricultural greenhouse equipped with an EAHE. Bansal et al. [63] have studied numerically the heating capacity of an airto-ground heat exchanger. The results were validated using experimental data show an increase of 4.1 to $4.8{ }^{\circ} \mathrm{C}$ in air temperature passing through the device.

An implicit-transient (variable) model was developed by Bansal et al. [64] to predict the cooling capabilities of an airto-ground heat exchanger. The study is validated by experimental data. 8 to $12.7^{\circ} \mathrm{C}$ is the reduction of the air temperature passing through the device. The performance coefficient COP varies from 1.9 to 2.9 depending on the air velocity ( 2 to $5 \mathrm{~m} / \mathrm{s}$ ). The coupling between EAHE and an evaporative cooling system is studied numerically by Bansal et al. [65]. The use of the air-ground heat exchanger technique has allowed better control and improved thermal comfort. Maerefat and Haghighi [66] studied the coupling of the EAHE with a solar chimney in the same building. The authors state that with the right design, the new system will be able to create a comfortable indoor thermal environment for a considerable number of hours in the summer period. A complete parametric analysis was conducted by Ghosal et al. [67] to study the ability of EAHE to provide the heating requirements of agricultural greenhouses. Kumara et al. [68] propose an EAHE design tool based on neural networks. Ghosal and Tiwari [69] conducted a study of the parameters affecting the operation of an air-ground heat exchanger integrated into a greenhouse. Nayak and Tiwari [70] conducted a theoretical study of a possible combination between EAHE and solar energy using photovoltaic panel for agricultural greenhouses conditioning purpose.

Kumar et al. [71] proposes a new method for designing and dimensioning EAHE based on the heating and cooling requirements of new buildings. Tittelein et al. [72] used a numerical model based on response method to reduce time required for simulation. Chel et al. [73] developed a thermal model using the $4^{\text {th }}$ degree Runge-Kutta method of a vaulted roof building connected to An EAHE. The results are validated by experimental data. The results showed that the difference in temperature between the air inside and outside the building was between 5 and $15^{\circ} \mathrm{C}$ for winter and summer respectively. They also found that the building's energysaving potential increased from $4946 \mathrm{kWh} /$ year to 10321 $\mathrm{kWh} /$ year. Also, the seasonal energy efficiency ratio (SEER) for ETAHE was 2 to 3. A study of the parameters influencing the performance of air-ground heat exchangers in arid regions was conducted by Hatraf et al. [74], such as the nature of the soil, depth, diameter of the pipe depth and induced airflow.

The coupling of EAHE and the photovoltaic-thermal energy of a solar panel connected to a greenhouse (located in Delhi, India) is studied by Nayak and Tiwari [75]. Its performance is evaluated over a year and finalized by an energy analysis. Also, a new PID control system associated with an air-ground heat exchanger was proposed to optimize its operation and ensure energy efficiency of the studied system. Gan [76] has developed a computer program to model and simulate heat and mass transfer between EAHE and the subsoil on its thermal performances for ventilation taking into account the dynamic variations of the climate and soil nature. The economic aspects of air-to-ground heat exchanger technique have been discussed by several researchers. Choudhury and Misra [77], Brum et al. 2018 [78], Taurines [79], Yang et al. [80], found that the EAHE technique is feasible and economically efficient while providing significant energy savings. Diaz et al. [81] use a system based on flow logic to ensure energy savings while improving the performance of an EAHE. Other studies on solar collector/heat exchanger channels can be found in previous studies [82-85].

\section{ADVANTAGES AND DISADVANTAGES OF EAHE AIR-TO-GROUND EXCHANGERS}

The air-ground heat exchanger has the following advantages:

- Simplicity of design and installation;

- Adaptation to several types of soil;

- For fully buried air-ground heat exchangers, the air outlet temperature depends only the inlet air 
temperature and the subsoil temperature;

- Air is used as a working fluid;

- Does not require energy for its operation in case of high wind speeds;

- Requires less maintenance with lower costs; and

- No pollution or greenhouse gas due to absence of any source of combustion.

Despite these advantages, the technique has the following disadvantages:

- High installation price;

- Condensation phenomenon inside the tube of the exchanger and possible development of microorganisms which reduces the indoor air quality;

- Outlet air temperature is non-uniform; and

- High dependence to local climatic conditions in the presence of the upper parts of the tube above the ground, which influence directly and indirectly the thermal performance of the device.

\section{CONCLUSION}

The air-ground heat exchanger is an ancient technique invented by the Iranians before 3000 years A.C or they were called Qanât. Qanât is an underground network of water also serves as air ducts where the air in contact with the water loses some degrees. The air after its journey in the Qanats is injected into the living space, which creates more comfortable thermal environments inside buildings especially in arid regions. Using an air-to-ground heat exchanger for thermal comfort requires a deep understanding of geothermal deposits and these natural potentials and particularly in desert and arid regions.

\section{REFERENCES}

[1] Nomur, M., Hiyama, K. (2017). A review: Natural ventilation performance of office buildings in Japan. Renewable and Sustainable Energy Reviews, 74: 746754. https://doi.org/10.1016/j.rser.2017.02.083

[2] Zakaria, A.A.N.M., Baharum, A.C.M.A.M.R. (2015). A review on natural ventilation applications through building façade components and ventilation openings in tropical climates. Energy and Buildings, 101: 153-162. https://doi.org/10.1016/j.enbuild.2015.04.033

[3] Ishugah, T.F., Li, Y., Wang, R.Z., Kiplagat, J.K. (2014). Advances in wind energy resource exploitation in urban Environment: A review. Renewable and Sustainable Energy Reviews, 37: 613-626. https://doi.org/10.1016/j.rser.2014.05.053

[4] Khan, N., Su, Y., Riffat, S.B. (2008). A review on wind driven ventilation techniques. Energy and Buildings, 40: 1586-1604.

https://doi.org/10.1016/j.enbuild.2008.02.015

[5] van Hooff, T., Blocken, B., Aanen, L., Bronsema, B. (2011). A venturi-shaped roof for wind-induced natural ventilation of buildings: wind tunnel and CFD evaluation of different design configurations. Building and Environment, 46: 1797-1807. https://doi.org/10.1016/j.buildenv.2011.02.009
[6] Allard, F. (1998). Natural ventilation in buildings: A design handbook. F. Allard (Ed.). London: James \& James, pp. 12-78.

[7] Battle, M.C. (1999). Consulting engineers. Wind towers: detail in building, London: Academy Press.

[8] Samsam-Khayani, H., Tavakoli, M.R., Mohammadshahi, S., Nili-Ahmadabadi, M. (2018). Numerical study of effects of Shavadoon connections (a vernacular architectural pattern) on improvement of natural ventilation. Tunnelling and Underground Space Technology, 82: 170-181. https://doi.org/10.1016/j.tust.2018.08.045

[9] Xie, B., Han, Y., Huang, H., Chen, L., Zhou, Y., Fan, C., Liu, X. (2018). Numerical study of natural ventilation in urban shallow tunnels: Impact of shaft cross section. Sustainable Cities and Society, 42: 521-537. https://doi.org/10.1016/j.scs.2018.07.022

[10] Omrani, S., Garcia-Hansen, V., Capra, B., Drogemuller, R. (2017). On the effect of provision of balconies on natural ventilation and thermal comfort in high-rise residential buildings. Building and Environment, 123: 504-516. https://doi.org/10.1016/j.buildenv.2017.07.016

[11] Zhai, Z., El-Mankibi, M., Zoubir, A. (2015). Review of natural ventilation models. Energy Procedia, 78: 27002705. https://doi.org/10.1016/j.egypro.2015.11.355

[12] Cherier, M.K., Benouaz, T., Bekkouche, S.M.A., Hamdani, M. (2018). Some solar passive concepts in habitat through natural ventilation case study: Dry climate in Algeria Ghardaia. Case Studies in Thermal Engineering, 12: 1-7. https://doi.org/10.1016/j.csite.2018.02.002

[13] Nikas, K.S., Nikolopoulos, N., Nikolopoulos, A. (2014). Numerical study of a naturally cross-ventilated building. Energy and Buildings, 42: 422-434. https://doi.org/10.1016/j.enbuild.2009.10.010

[14] Perén, J.I., Van Hooff, T., Leite, B.C.C., Blocken, B. (2015). CFD analysis of cross-ventilation of a generic isolated building with asymmetric opening positions: impact of roof angle and opening location. Building and Environment, 85 : 263-276. https://doi.org/10.1016/j.buildenv.2014.12.007

[15] Faggianelli, G.A., Brun, A., Wurtz, E., Muselli, M. (2014). Natural cross ventilation in buildings on Mediterranean coastal zones. Energy and Buildings, 77: 206-218. https://doi.org/10.1016/j.enbuild.2014.03.042

[16] Jomehzadeh, F., Nejat, P., Calautit, J.K., Yusof, M.B.M., Zaki, S.A., Hughes, B.R., Yazide, M.N.A.W.M. (2017). A review on wind catcher for passive cooling and natural ventilation in buildings, Part 1: Indoor air quality and thermal comfort assessment. Renewable and Sustainable Energy Reviews, 70: 736756. https://doi.org/10.1016/j.rser.2016.11.254

[17] Gładyszewska-Fiedoruk, K., Gajewski, A. (2012). Effect of wind on stack ventilation performance. Energy and Buildings, 51: 242-247. https://doi.org/10.1016/j.enbuild.2012.05.007

[18] Khan, N., Su, Y., Riffat, S.B. (2008). A review on wind driven ventilation techniques. Energy and Buildings, 40: 1586-1604. https://doi.org/10.1016/j.enbuild.2008.02.015

[19] Pan, W., Liu, S., Li, S., Cheng, X., Zhang, H., Long, Z., Zhang, T.F., Chen, Q. (2019). A model for calculating single-sided natural ventilation rate in an urban 
residential apartment. Building and Environment, 147, 372-381. https://doi.org/10.1016/j.buildenv.2018.08.047

[20] Sacht H., Bragança L., Almeida, M., Caram, R. (2016). Study of natural ventilation in wind tunnels and influence of the position of ventilation modules and types of grids on a modular façade system. Energy Procedia, 96:

953-964 https://doi.org/10.1016/j.egypro.2016.09.173

[21] Perez-Lombard, L., Ortiz, J., Pout, C. (2008). A review on buildings energy consumption information. Energy and Buildings, 40: 394-398. https://doi.org/10.1016/j.enbuild.2007.03.007

[22] Santamouris, M., Agas, G., Matsaggos, T., Agririou, A. (1993). Use of environmental heat sinks for heat dissipation. Energy and buildings, 17: 321-329.

[23] Kaur, J., Singh, P., Kaur, H. (2015). A review on the experimental and analytical analysis of earth air tunnel heat exchanger system. Environmental Sustainability: Concepts, Principles, Evidences and Innovations, 15(9): 116-120. https://doi.org/10.1016/j.rser.2011.07.103

[24] Ahmed, A., Ip, K., Miller, A., Gidado, K. (2009). Thermal performance of earth-air heat exchanger for reducing cooling energy demand of office buildings in the United Kingdom. In 11th Conference of International Building Performance Simulation Association, 2009: 2228-2235.

[25] Breesch, H., Bossaer, B., Janssens, A. (2005). Passive cooling in a low energy office building. Energy Build, 45:

215-222.

https://doi.org/10.1016/j.solener.2004.12.002

[26] Sobti, J., Singh, S.K. (2015). Earth-air heat exchanger as a green retrofit for Chandīgarh-a critical review. Geothermal Energy, 3: 14 https://doi.org/10.1186/s40517-015-0034-4

[27] Badescu, V. (2007). Simple and accurate model for the ground heat exchanger of a passive house. Renew Energy, 32:

845-55. https://doi.org/10.1016/j.renene.2006.03.004

[28] Ali, S., Muhammad, N., Amin, A., Sohaib, M., Basit, A., Ahmad, T. (2019). Parametric optimization of earth to air heat exchanger using response surface method. Sustainability, $11(11)$ : 3186. https://doi.org/10.3390/su11113186

[29] Mihalakakou, G., Santamouris, M., Lewis, O., Asimakopoulos, D. (1997). On the application of the energy balance equation to predict ground temperature profiles. Solar Energy, 60(3/4): 181-190. https://doi.org/10.1016/S0038-092X(97)00012-1

[30] Popiel, C., Wojtkowiak, J., Biernacka, B. (2001). Measurements of temperature distribution in ground. Experimental Thermal and Fluid Science, 25: 301-309. https://doi.org/10.1016/S0894-1777(01)00078-4

[31] Al-Ajmi, F., Loveday, D.L., Hanby, V.I. (2006). The cooling potential of earth-air heat exchangers for domestic buildings in a desert climate. Building and Environment, 41 : 235-244 https://doi.org/10.1016/j.buildenv.2005.01.027

[32] Bojic, M., Trifunovic, N., Papadakis, G., Kyritsis, S. (1997). Numerical simulation, technical and economic evaluation of air-to-earth heat exchanger coupled to a building. $\quad$ Energy, 22(12): 1151-1158. https://doi.org/10.1016/S0360-5442(97)00055-8

[33] De Paepe, M., Willems, N. (2001). 3D unstructured modeling technique for ground-coupled air heat exchangers. In Proceedings of the 7th International World Conference CLIMA2000, Napoli.

[34] Gauthier, C., Lacroix, M., Bernier, H. (1997). Numerical simulation of soil heat exchanger-storage systems for greenhouses. Solar Energy, 60(6): 333-346.

[35] Bojic, M., Papadakis, G., Kyritsi, S. (1999). Energy from a two-pipe, earth-to-air heat exchanger. Energy, 24 519-523. https://doi.org/10.1016/S03605442(99)00012-2

[36] Chaturvedi, A.K., Bartaria, V.N. (2015). Performance of earth tube heat exchanger cooling of air-a review. Int J Mech Eng Robotics Res, 4(1): 378-382.

[37] Bisoniya, T.S., Kumar, A., Baredar, P. (2013). Experimental and analytical studies of earth-air heat exchanger (EAHE) systems in India: A review. Renewable and Sustainable Energy Reviews, 19: 238246. https://doi.org/10.1016/j.rser.2012.11.023

[38] Bisoniya, T.S., Kumar, A., Baredar, P. (2014). Study on calculation models of earth-air heat exchanger systems. Journal of Energy, 2014: 859286. https://doi.org/10.1155/2014/859286

[39] Ozgener, L., Ozgener, O. (2015). The Use of EAHEs: 2015 Turkey Review. In Department of Mechanical Engineering, Faculty of Engineering, Celal Bayar University Muradiye, Manisa, Turkey, Proceedings World Geothermal Congress.

[40] Naik, B.D., Mundla, S.R. (2016). Research review on earth pipe air conditioning system. International Research Journal of Engineering and Technology, 3(12) 1237-1240.

[41] Rawat, P., Kapoor, A. (2016). Recent advances in heating and cooling using earth air heat exchanger (EAHE): A review. IJEDR, 4(2): 2321-9939.

[42] Trombe, A., Pettit, M., Bourret, B. (1991). Air cooling by earth tube heat exchanger: experimental approach. Renewable Energy, 1(5/6): 699-707. https://doi.org/10.1016/0960-1481(91)90016-I

[43] Tzaferis, A., Liparakis, D., Santamouris, M., Argiriou, A. (1992). Analysis of the accuracy and sensitivity of eight models to predict the performance of earth-to-air heat exchangers. Energy and Buildings, 18: 35-43. https://doi.org/10.1016/0378-7788(92)90049-M

[44] Vaz, J., Sattler, M.A., dos Santos, E.D., Isoldi, L.A. (2011). Experimental and numerical analysis of an earth-air heat exchanger. Energy and Buildings, 43: 2476-2482. https://doi.org/10.1016/j.enbuild.2011.06.003

[45] Ghosal, M.K., Tiwari, G.N., Srivastava, N.S.L. (2004). Thermal modeling of a greenhouse with an integrated earth to air heat exchanger: an experimental validation. Energy and Buildings, 36: 219-227. https://doi.org/10.1016/j.enbuild.2003.10.006

[46] Tiwari, G.N., Akhtar, M.A., Shukla, A., Kha, M.E. (2006). Annual thermal performance of greenhouse with an earth-air heat exchanger: An experimental validation. Renewable Energy, 31: 2432-2446. https://doi.org/10.1016/j.renene.2005.11.006

[47] Bansal, V., Misra, R., Agarwal, G.D., Mathur, J. (2013). Derating Factor' new concept for evaluating thermal performance of earth air tunnel heat exchanger: A transient CFD analysis. Applied Energy, 102: 418-426. https://doi.org/10.1016/j.apenergy.2012.07.027

[48] Li, H., Yu, Y., Niu, F., Shafik, M., Chen, B. (2014). Performance of a coupled cooling system with earth-to- 
air heat exchanger and solar chimney. Renewable Energy, 62: 468-477. https://doi.org/10.1016/j.renene.2013.08.008

[49] Misraa, R., Bansala, V., Agarwala, G.D., Mathura, J., Aseri, T. (2012). Thermal performance investigation of hybrid earth air tunnel heat exchanger. Energy and Buildings, 49:

531-535. https://doi.org/10.1016/j.enbuild.2012.02.049

[50] Soni, S.K., Pandey, M., Bartaria, V.N. (2016). Energy metrics of a hybrid earth air heat exchanger system for summer cooling requirements. Energy and Buildings, 129: 1-8. https://doi.org/10.1016/j.enbuild.2016.07.063

[51] Belloufi, Y., Brima, A., Zerouali, S., Atmani, R., Aissaoui, F., Rouag, A., Moummi, N. (2017). Numerical and experimental investigation on the transient behavior of an earth air heat exchanger in continuous operation mode. International Journal of Heat and Technology, 35(2): 279-288. https://doi.org/10.18280/ijht.350208

[52] Menhoudj, S., Mokhtari, A.M., Benzaama, M.H., Maalouf, C., Lachi, M., Makhlouf, M. (2017). Study of the energy performance of an earth - air heat exchanger for refreshing buildings in Algeria. Energy and Buidings, 158: 1602-1612. https://doi.org/10.1016/j.enbuild.2017.11.056

[53] Sehli, A., Hasni, A., Tamali, M. (2012). The potential of earth-air heat exchangers for low energy cooling of buildings in South Algeria. Energy Procedia, 18: 496506. https://doi.org/10.1016/j.egypro.2012.05.061

[54] Misra, R., Jakhar, S., Agrawal, K.K., Sharma, S., Jamuwa, D.K., Soni, M.S., Agrawal, G.D. (2018). Field investigations to determine the thermal performance of earth air tunnel heat exchanger with dry and wet soil: Energy and exergetic analysis. Energy \& Buildings, 171: 107-115. https://doi.org/10.1016/j.enbuild.2018.04.026

[55] Kappler, G., Dias, J.B., Haeberle, F., Wander, P.R., Moraes, C.A.M. (2018). Study of an earth-to-water heat exchange system which relies on underground water tanks. Renewable Energy, 133: 1236-1246. https://doi.org/10.1016/j.renene.2018.09.004

[56] Jakhar, S., Misra, R., Soni, M.S., Gakkhar, N. (2016). Parametric simulation and experimental analysis of earth air heat exchanger with solar air heating duct. Engineering Science and Technology, 19: 1059-1066. https://doi.org/10.1016/j.jestch.2016.01.009

[57] Chiesa, G. (2017). Climate-potential of earth-to-air heat exchangers. Enery Procedia, 122: 517-522. https://doi.org/10.1016/j.egypro.2017.07.300

[58] Congedo, P.M., Lorusso, C., De Giorgi, M.G., Marti, R., D'Agostino, D. (2016). Horizontal air-ground heat exchanger performance and humidity simulation by computational fluid dynamic analysis. Energies, 9(11): 930. https://doi.org/10.3390/en9110930

[59] Wei, H., Yang, D., Guo, Y., Chen, M. (2018). Coupling of earth-to-air heat exchangers and buoyancy for energy efficient ventilation of buildings considering dynamic thermal behaviour and cooling/heating capacity. Energy, 147: https://doi.org/10.1016/j.energy.2018.01.067

[60] Su, H., Liu, X.B., Ji, L., Mu, J.Y. (2012). A numerical model of a deeply buried air-earth-tunnel heat exchanger. Energy and Buildings, 48: 233-239. https://doi.org/10.1016/j.enbuild.2012.01.029
[61] Ramírez-Dávila, L., Xamán, J., Arce, J., Álvarez, G., Hernández-Pérez, I. (2014). Numerical study of earthto-air heat exchanger for three different climates. Energy and Buildings, 76: 238-248. https://doi.org/10.1016/j.enbuild.2014.02.073

[62] Shukla, A., Tiwari, G.N., Sodha, M.S. (2006). Thermal modeling for greenhouse heating by using thermal curtain and an earth-air heat exchanger. Building and Environment, 41: 843-850. https://doi.org/10.1016/j.buildenv.2005.04.014

[63] Bansal, V., Misra, R., Agrawal, G.D., Mathur, J. (2009) Performance analysis of earth-pipe-air heat exchanger for winter heating. Energy and Buildings, 41: 11511154. http://dx.doi.org/10.1016/j.enbuild.2009.05.010

[64] Bansal, V., Misra, R., Agrawal, G.D., Mathur, J. (2010). Performance analysis of earth-pipe-air heat exchanger for summer cooling. Energy and Buildings, 42: 645-648. https://doi.org/10.1016/j.enbuild.2009.11.001

[65] Bansal, V., Misra, R., Agrawal, G.D., Mathur, J. (2012). Performance evaluation and economic analysis of integrated earth-air-tunnel heat exchanger-evaporative cooling system. Energy and Buildings, 55: 102-108. https://doi.org/10.1016/j.enbuild.2012.08.047

[66] Maerefat, M., Haghighi, A.P. (2010). Passive cooling of buildings by using integrated earth to air heat exchanger and solar chimney. Renewable Energy, 35: 2316-2324. https://doi.org/10.1016/j.renene.2010.03.003

[67] Ghosal, M.K., Tiwari, G.N., Das, D.K., Pandey, K.P. (2005). Modeling and comparative thermal performance of ground air collector and earth air heat exchanger for heating of greenhouse. Energy and Buildings, 37: 613621. https://doi.org/10.1016/j.enbuild.2004.09.004

[68] Kumara, R., Kaushik, S.C., Garg, S.N. (2006). Heating and cooling potential of an earth-to-air heat exchanger using artificial neural network, MS-808, Transportation research and injuries prevention programme (TRIPP). Renewable Energy 31: 1139-1155. https://doi.org/10.1016/j.renene.2005.06.007

[69] Ghosal, M.K., Tiwari, G.N. (2006). Modeling and parametric studies for thermal performance of an earth to air heat exchanger integrated with a greenhouse. Energy Conversion and Management, 47: 1779-1798. https://doi.org/10.1016/j.enconman.2005.10.001

[70] Nayak, S., Tiwari, G.N. (2009). Theoretical performance assessment of an integrated photovoltaic and earth air heat exchanger greenhouse using energy and exergy analysis methods. Energy and Buildings, 41: 888-896. https://doi.org/10.1016/j.enbuild.2009.03.012

[71] Kumar, R., Sinha, A.R.. Singh, K., Modhukalya, U. (2008). A design optimization tool of earth-to-air heat exchanger using a genetic algorithm. Renewable Energy, 33:

2282-2288. https://doi.org/10.1016/j.renene.2008.01.006

[72] Tittelein, P., Achard, G., Wurtz, E. (2009). Modelling earth-to-air heat exchanger behaviour with the convolutive response factors method. Applied Energy, 86:

https://doi.org/10.1016/j.apenergy.2009.02.010

[73] Chel, A., Tiwari, G.N. (2009). Performance evaluation and life cycle cost analysis of earth to air heat exchanger integrated with adobe building for New Delhi composite climate. Energy and Buildings, 41: 5666. https://doi.org/10.1016/j.enbuild.2008.07.006 
[74] Hatraf, N., Chabane, F., Brima, A., Moummi, N., Moummi, A. (2014). Parametric study of to design an earth to air heat exchanger with experimental validation. Engineering Journal, 18(2): 41-54 https://doi.org/10.4186/ej.2014.18.2.41

[75] Nayak, S., Tiwari, G.N. (2010). Energy metrics of photovoltaic/thermal and earth air heat exchanger integrated greenhouse for different climatic conditions of India. Applied Energy, 87: 2984-2993. https://doi.org/10.1016/j.apenergy.2010.04.010

[76] Gan, G. (2015). Simulation of dynamic interactions of the earth-air heat exchanger with soil and atmosphere for preheating of ventilation air. Applied Energy, 158: $118-132$ https://doi.org/10.1016/j.apenergy.2015.08.081

[77] Choudhury, T., Misra, A.K. (2014). Minimizing changing climate impact on buildings using easily and economically feasible earth to air heat exchanger technique. Mitigation and Adaptation Strategies for Global Change, 19(7): 947-954. https://doi.org/10.1007/s11027-013-9453-3. 2013.

[78] Brum, R.S., Ramalho, J.V., Rodrigues, M.K., Rocha, L.A., Isoldi, L.A., Dos Santos, E.D. (2019). Design evaluation of Earth-Air Heat Exchangers with multiple ducts. Renewable Energy, 135: 1371-1385. https://doi.org/10.1016/j.renene.2018.09.063

[79] Taurines, K., Girous-Julien, S., Menezo, C. (2019). Energy and thermal analysis of an innovative earth-toair heat exchanger: Experimental investigations. Energy and Buildings, 187: 1-15. https://doi.org/10.1016/j.enbuild.2019.01.037
[80] Yang, D., Wei, H., Shi, R., Wang, J. (2019). A demandoriented approach for integrating earth-to-air heat exchangers into buildings for achieving year-round indoor thermal comfort. Energy Conversion and Management, 182: 95-107. https://doi.org/10.1016/j.enconman.2018.12.071

[81] Diaz S.E., Sierra, J.M.T., Herrera, J.A. (2013). The use of earth-air heat exchanger and fuzzy logic control can reduce energy consumption and environmental concerns even more. Energy and Buildings, 65: 458-463. https://doi.org/10.1016/j.enbuild.2013.06.028

[82] Won, K.H., Lee, B.J. (2018). Effect of light scattering on the performance of a direct absorption solar collector. Front. Energy, 12(1): 169-177. https://doi.org/10.1007/s11708-018-0527-5

[83] Uddin, M.J., Alam, M.S., Rahman, M.M. (2017). Natural convective heat transfer flow of nanofluids inside a quarter-circular enclosure using nonhomogeneous dynamic model. Arab J. Sci. Eng, 42(5): 1883-1901. https://doi.org/10.1007/s13369-0162330-0

[84] Nasrin, R., Parvin, S., Alim, M.A. (2015). Heat transfer and collector efficiency through a direct absorption solar collector with radiative heat flux effect. Numerical Heat Transfer, Part A, 68: 887-907. https://doi.org/10.1080/10407782.2015.1023122

[85] Pustovalov, V.K. (2018). Heating of single nanoparticles, their assemblies and ambient medium by solar radiation. Nanotech. Environmental Engineering, 3(1): 7. https://doi.org/10.1007/s41204-018-0036-0 